\title{
MENGEMBANGKAN SDM UNGGUL DI DESA SIRNABAYA KECAMATAN TELUK JAMBE TIMUR
}

\author{
Arif Rahman Hakim', Giri Wahyu Putra ${ }^{2}$ \\ Fakultas Psikologi Universitas Buana Perjuangan Karawang \\ $\underline{\text { arif.hakim@ubpkarawang.ac.id }}^{{ }^{1},} \underline{\text { If17.giriputra@ @ms.ubpkarawang.ac.id }}^{2}$
}

\begin{abstract}
ABSTRAK
Sebagai daerah yang berubah fungsi menjadi daerah industri, Kabupaten Karawang memiliki slogan baru, yaitu Karawang sebagai kota industri. Tantangan bagi penduduk Karawang adalah kesiapan memasuki dunia industri, keterampilan sebagai petani bagi penduduk Karawang sudah tidak diragukan lagi, akan tetapi memasuki dunia industri, maka pengetahuan, keterampilan serta sikap yang dimiliki perlu dilatih dan dikembangkan agar siap menghadapi era industri. Pengabdian ini bertujuan untuk mendapatkan gambaran terkait sumber daya manusia di desa Sirnabaya. Instrumen yang digunakan dalam pengabdian ini adalah dengan menggunakan kuesioner profil desa berkelanjutan. Teknik pengumpulan data dengan melakukan interviu dengan pihak perwakilan desa yang ditunjuk oleh kepala desa Sirnabaya. Sumber data diklasifikasikan menjadi dua yaitu data primer dan data sekunder. Data primer diperoleh melalui kuesioner, sedangkan data sekunder diperoleh melalui laporan dari Badan Pusat Statistik Nasional. Data hasil kuesioner tersebut dijadikan sebagai dasar pembuatan rancangan program untuk pengembangan SDM unggul di Desa Sirnabaya.
\end{abstract}

Kata kunci: Sumber daya manusia, pelatihan dan pengembangan

\begin{abstract}
As an area that has changed its function to an industrial area, Karawang Regency has a new slogan, namely Karawang as an industrial city. The challenge for Karawang residents is a readiness to enter the industrial world, skills as farmers for Karawang residents are no longer in doubt, but entering the world industry, their knowledge, skills, and attitudes are necessary and developed to be ready to face the industry. This service aims to get an overview of human resources in Sirnabaya village. The instrument used in this service was to use a sustainable village profile questionnaire. The data technique was conducted by conducting interviews with village representatives appointed by the village head of Sirnabaya. There are two sources of classification data, namely primary data and secondary data. Primary data were obtained through questionnaires, while data were obtained through reports from the National Statistics Agency. The data from the questionnaire was used as the basis for making a program design for the development of superior human resources in Sirnabaya Village.
\end{abstract}

Keywords: Human resources, training, and development 


\section{PENDAHULUAN}

Karawang merupakan salah satu daerah di Jawa Barat yang mengalami perubahan cukup signifikan, dari daerah pertanian yang mendapat julukan lumbung padi, kini telah berubah menjadi salah satu kawasan industri terbesar di Indonesia.

Salah satu investor terbesar datang dari negara Jepang, para investor dari negara Jepang ini fokus menanamkan investasinya dalam rangka membangun industri di daerah Karawang, luas wilayah yang direncanakan adalah sekitar 3.000 hektar, yang diperuntukkan industri otomotif, elektronik, komponen, permesinan, dan IT (finance.detik.com, 2013).

Sebagai daerah yang berubah fungsi menjadi daerah industri, Karawang memiliki slogan baru, yaitu Karawang sebagai kota industri (Safana, 2019). Tantangan bagi penduduk Karawang adalah kesiapan memasuki dunia industri, keterampilan sebagai petani bagi penduduk Karawang sudah tidak diragukan lagi, akan tetapi pada saat memasuki dunia industri, maka pengetahuan, keterampilan serta sikap yang dimiliki perlu dikembangkan agar siap menghadapi era industri.

Ketidaksiapan menghadapi dunia industri akan menyebabkan pengangguran, karena kompetensi yang diinginkan oleh pihak industri belum dimiliki oleh 
masyarakat sekitar. Menurut Kepala Dinas Tenaga Kerja Kabupaten Karawang sekitar 9,5 persen dari total penduduk Karawang yang berjumlah 2,9 juta jiwa masih menganggur (Safana, 2019). 9,5 persen merupakan angka yang cukup tinggi, didapatkan sekitar 102.000 orang yang masih menganggur.

Melihat masih tingginya angka pengangguran di daerah Karawang, maka perlu kiranya dilakukan penelitian terkait gambaran sumber daya manusia di tiap desa, agar pemerintah daerah bisa membuat rencana pengembangan sumber daya yang dimiliki, sehingga dapat terserap di berbagai sektor.

Salah satu usaha untuk meningkatkan kompetensi sumber daya masyarakat suatu desa adalah dengan memberikan pelatihan dan pengembangan untuk meningkatkan ketrampilan kerja di berbagai sektor industri. Menurut Kaswan (2016) pelatihan adalah sebuah proses yang bertujuan meningkatkan pengetahuan dan ketrampilan karyawan. Sedangkan menurut Sikula (dalam Munandar, 2001) Pelatihan adalah proses pendidikan jangka pendek dengan mempergunakan prosedur yang sistematis dan terorganisir, dengan tujuan meningkatkan pengetahuan dan keterampilan teknis tenaga kerja non manajerial sesuai dengan kebutuhan kerja.

Berdasarkan definisi pelatihan di atas dapat disimpulkan bahwa pelatihan 
adalah sebuah proses pendidikan jangka pendek, sebagai sebuah proses memiliki makna bahwa pelatihan terdiri dari rangkaian dan runtunan kegiatan. Sedangkan pendidikan jangka pendek memiliki makna kegiatan yang dilakukan berdurasi pendek dan tidak memakan waktu sampai bertahun-tahun. Sistematis dan terorganisir berarti kegiatan yang dilakukan diatur dan diorganisir secara teratur dan baik. Tujuan dari pelatihan adalah untuk meningkatkan pengetahuan dan keterampilan teknis tenaga kerja non manajerial yang berarti pengetahuan dan keterampilan lebih teknis sesuai dengan kebutuhan pekerjaan waktu itu.

Pengembangan adalah proses pendidikan jangka panjang dengan menggunakan prosedur sistematis dan terorganisir, sehingga tenaga manajerial dapat mempelajari pengetahuan konseptual dan teoritis untuk tujuan umum (Munandar, 2001). Sedangkan menurut Kaswan (2016) merupakan proses pendidikan di mana karyawan mendapatkan keterampilan dan pengalaman agar berhasil pada pekerjaan atau tugas sekarang dan di masa yang akan datang.

Pelatihan memiliki pengaruh yang signifikan terhadap kinerja karyawan, sehingga diharapkan calon pekerja yang sudah dilatih dapat dilirik oleh pengusaha untuk dipekerjakan dengan keyakinan bahwa calon pekerja tersebut dapat 
memberikan kontribusi yang signifikan terhadap kinerja perusahaan. Hal ini sesuai hasil sebuah penelitian yang menyatakan bahwa kegiatan pelatihan memiliki pengaruh terhadap kinerja karyawan dalam sektor pelayanan perbankan syariah (Badawi, Hartati, \& M, 2018).

Penelitian lain juga menguatkan pendapat di atas, bahwa pelatihan yang dilakukan pada saat transisi pada satu kelompok memiliki perbedaan kinerja yang signifikan bila dibandingkan dengan kelompok yang tidak melakukan pelatihan (D'Elia, D'isanto, \& Altavilla, 2019).

\section{METODE}

Metode pengabdian ini terdiri dari program kegiatan, analisa kebutuhan program, model atau pendekatan yang digunakan dalam menjalankan program, peserta yang terlibat, penyelesaian masalah di lapangan ataupun dilingkungan kegiatan pengabdian, hasil yang diinginkan dalam menjalankan program.

\section{Program kegiatan}

Program kegiatan ini berupa pengisian data kuesioner potensi dan perkembangan desa terkait profil desa berkelanjutan. Narasumber untuk pengisian kuesioner ini adalah pihak aparatur desa dan pihak terkait lainnya. 


\section{Analisa kebutuhan program}

Setelah melakukan pengisian kuesioner profil desa berkelanjutan, dilakukan analisa terkait program-program yang dibutuhkan untuk pengembangan sumber daya yang unggul.

\section{Pendekatan dalam menjalankan program pengabdian}

Pendekatan yang digunakan adalah menggunakan Instrumen kuesioner profil desa berkelanjutan. Teknik pengumpulan data dengan melakukan interviu dengan pihak perwakilan desa yang ditunjuk oleh kepala desa Sirnabaya. Sumber data diklasifikasikan menjadi dua yaitu data primer dan data sekunder. Data primer diperoleh melalui kuesioner, sedangkan data sekunder diperoleh melalui laporan dari Badan Pusat Statistik Nasional.

\section{Waktu dan Tempat Pengabdian}

Pengabdian ini dilaksanakan pada tanggal 1 Agustus - 30 Agustus 2020, tempat pelaksanaan pengabdian adalah di desa Sirnabaya Kecamatan Teluk Jambe Timur Kabupaten Karawang.

\section{Target/Subjek Pengabdian}

Pengabdian ini untuk mengetahui gambaran sumber daya manusia berupa usia produktif dan tingkat pendidikan masyarakat di desa Sirnabaya. Gambaran SDM tersebut sebagai dasar pembuatan program yang akan diajukan ke pihak Desa dalam rangka mengembangkan SDM yang unggul. 


\section{Peserta yang terlibat}

Peserta yang terlibat dalam pengabdian ini adalah Dosen, serta mahasiswa dari berbagai macam program studi, antara lain : Prodi Manajemen, SI, TI, Akuntansi, Psikologi, Farmasi dan Pendidikan.

\section{Hasil yang diinginkan dalam menjalankan program}

Hasil program yang diinginkan adalah terisinya kuesioner potensi dan perkembangan desa terkait profil desa berkelanjutan, untuk diserahkan ke pihak desa dan pihak terkait. Memetakan potensi sumber daya untuk pembuatan program- program yang dibutuhkan.

\section{HASIL DAN PEMBAHASAN}

Berdasarkan data penduduk laki- laki dan perempuan didapatkan data sebesar 9.194 dengan tingkat sex ratio sebesar

109.67. Usia kerja produktif juga terlihat cukup tinggi, untuk usia 20-29 tahun sebesar 1.604, sedangkan untuk usia 30-39 tahun 1.566, dan 40-49 tahun sebesar 980 orang. Dari jumlah orang sesuai profesi yang terbanyak adalah karyawan dari perusahaan swasta sebesar 1800 orang, lihat tabel 1. 
Tabel 1. Jenis profesi dan jumlah dalam orang.

\begin{tabular}{clr}
\hline No. & Profesi & Jumlah \\
\hline 1 & Buruh tani & 375 \\
2 & Petani & 20 \\
3 & Guru swasta & 102 \\
4 & Buruh harian lepas & 570 \\
5 & PNS & 250 \\
6 & Pedagang & \\
& Kelontong & 30 \\
7 & Pedagang keliling & 20 \\
8 & Wiraswasta & 245 \\
9 & Dokter & 10 \\
& Karyawan & \\
& Perusahaan swasta & 1800 \\
& Karyawan & \\
11 & Perusahaan & \\
& pemerintah & 15 \\
12 & Montir & 0 \\
13 & Nelayan & 9 \\
14 & Perangkat Desa & 10 \\
15 & Pengrajin & 15 \\
16 & Bidan & 10 \\
17 & Dosen Swasta & \\
\hline
\end{tabular}

Program-program berbasis IT untuk memudahkan proses pelatihan dan pengembangan dapat dibuat di tingkat desa, salah satunya melalu website. Berikut contoh rancang bangun aplikasi pelatihan dengan menggunakan website.

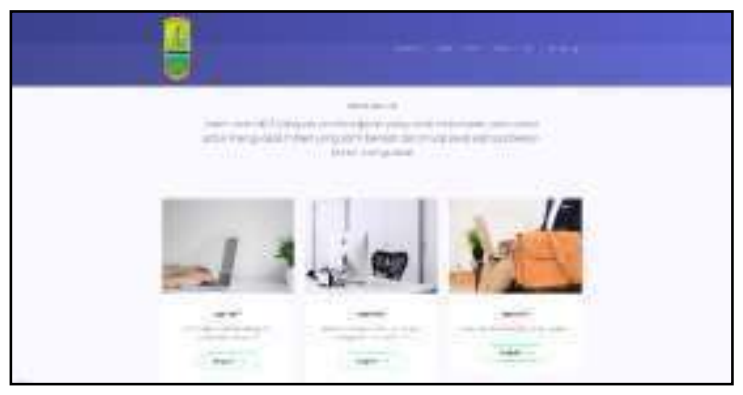

Gambar 1. Rancang bangun sistem pembelajaran komputerasi berbasis web 
Kebutuhan akan bantuan psikologis terhadap beberapa penduduk desa juga cukup dibutuhkan, meskipun jumlah penyintas gangguan mental, anak jalanan dan terlantar tidak terlalu banyak.

Pengembangan dibidang UMKM juga perlu ditingkatkan dengan adanya rumah makan, restoran, industri makanan, Bumdes, dan industri material bahan bangunan. Berikut lembaga ekonomi desa Sirnabaya.

Tabel 2 Jenis lembaga ekonomi desa

Sirnabaya

Rumah makan dan restoran

Industri makanan

Bumdes

Industri material bahan bangunan
Jenis Lembaga Ekonomi Jumlah 15

\section{KESIMPULAN DAN SARAN}

Jumlah tenaga kerja produktif yang bekerja di perusahaan atau bidang industri memiliki jumlah yang cukup tinggi dibandingkan dengan jenis profesi lainnya. Hal ini berimplikasi kepada jenis pelatihan dan pengembangan yang akan diberikan oleh pihak pemerintah desa. Terutama bagi lulusan sekolah menengah atas atau setingkat STM. Meskipun pekerja di bidang industri lebih banyak, pemerintah desa juga bisa mengoptimalkan pelatihan dan pengembangan untuk profesi lainnya, terutama bagi mereka yang tidak bekerja di 
Arif Rahman Hakim, Giri Wahyu Putra

Vol. 3 No 2, Agustus 2021

ISSN 2657-0203

e-ISSN 2686-0244

perusahaan. Selain itu jumlah lembaga ekonomi juga cukup banyak, sehingga perlu mendapat perhatian dan pengembangan lebih lanjut.

Kemampuan perangkat desa dalam bidang IT juga perlu mendapat perhatian dalam rangka meningkatkan kompetensi dibidang IT, sehingga mampu memberikan pelayanan yang maksimal ke setiap warga.

Dalam pelaksanaan pengabdian ini masih banyak sekali hambatan sehingga 
terasa kurang optimal, salah satunya adalah kasus pandemi Covid-19 yang masih tinggi. Saran untuk peserta pengabdian selanjutnya untuk lebih banyak berinteraksi dengan aparatur dan penduduk desa, sehingga analisa kebutuhan program pengabdian bisa lebih sesuai dan bermanfaat bagi masyarakat sekitar.

\section{DAFTAR PUSTAKA}

Badan Pusat Statistik Kabupaten Karawang. (2018). Kecamatan Teluk Jambe Timur dalam angka. Karawang: BPS Kabupaten Karawang.

Badawi, Hartati, W., \& M, H. S. (2018). Program pelatihan dan kinerja pada industri perbankan syariah. Jurnal Manajemen Bisnis, Vol 7 No. 2, 117-135.

D'Elia, F., D'isanto, T., \& Altavilla, G. (2019). Training and performance in the transition period. Journal of Human Sport and Exercise, 14, 258-262.

finance.detik.com. (2013). https://finance.detik.com/berita-ekonomi-bisnis. Dipetik Oktober 13, 2020, dari https://finance.detik.com/berita-ekonomi-bisnis/d-2441281/karawangdulu-lumbung-padi-sekarang-kawasan-industri

Kaswan. (2016). Pelatihan dan pengembangan untuk meningkatkan kinerja SDM. Bandung: Alfabeta.

Munandar, A. S. (2001). Psikologi industri dan organisasi. Jakarta: UI-Press.

Safana, I. (2019). jabarnews.com. Dipetik Oktober 14, 2020, dari https://jabarnews.com/read/79299/pengangguran-di-karawang-tercatat-mencapai102000-orang/2

Sugiyono. (2007). Statistika untuk penelitian. Bandung: Alfabeta. 